\title{
Josef Isensee
}

\section{Demokratyczne państwo prawa i jego przyszłość}

\section{The Democratic State of Law and Its Future}

Artykuł wychodząc od spostrzeżenia, że demokratyczne państwo prawa jest najbardziej wymagającą i odważną formą państwowości ukazuje najistotniejsze współczesne wyzwania państwa konstytucyjnego. Autor podejmuje m.in. problemy związane z formalnym pojmowaniem demokracji, nieufnym stosunkiem do kategorii narodu, skutkami potężnych ruchów migracyjnych, ekspansją sądownictwa konstytucyjnego czy terroryzmem.

Słowa kluczowe: demokracja, państwo prawa, Europa, konstytucja, wyzwania

Starting with the observation that the democratic state of law is the most demanding and courageous form of statehood, the article presents the most important contemporary challenges to the constitutional state. The author addresses the issues of the formal understanding of democracy, the mistrust towards the category of nation, the consequences of the powerful migration movements, the expansion of constitutional judiciary and the issue of terrorism.

Key words: democracy, state of law, Europe, constitution, challenges

\section{Państwo wolnościowe - akt odwagi}

Nie ma bardziej wymagającej i odważnej formy państwowości niż demokratyczne państwo prawa, które opiera się na wolności jednostki i woli narodu; które stawia na inicjatywę prywatną, odpowiedzialność osobistą i konkurencję oraz oczekuje solidarności; które ufa, że zapewniając wolność, zdoła zrealizować wszystkie swoje zadania, nie mając jednocześnie żadnej reasekuracji na wypadek, gdyby decyzje narodu miały doprowadzić do nieszczęścia, a siły wolności zawieść.

Jak wskazał hiszpański filozof José Ortega y Gasset, w demokratycznym państwie prawa panuje „polityczna zasada rządów prawa”, zgodnie z którą władza publiczna - choć jest wszechmogąca - sama się ogranicza, nawet jeśli ma na tym ucierpieć, a w państwie, którym 
rządzi, jest miejsce dla osób, które myślą i czują inaczej - inaczej niż „ci silni”, inaczej niż większość. Filozof chwali tę niezmierną wspaniałomyślność - prawo, jakie większość przyznaje mniejszości, a tym samym najszlachetniejsze hasło, jakie kiedykolwiek wybrzmiało na naszej planecie, głoszące decyzję o tym, by pokojowo współżyć z wrogiem, a zwłaszcza takim, który jest słaby. „Prawdopodobieństwo, że ludzkość wynajdzie coś tak pięknego, uduchowionego, karkołomnego i niezgodnego z naturą, było znikome”. Dlatego też „nie ma, co się dziwić” - pisze Ortega w 1930 r., między dwiema wojnami światowymi - „że teraz ta sama ludzkość wydaje się zdecydowana porzucić tę ideę. Jej realizacja jest zbyt trudna i złożona, żeby mogła się ona zakorzenić na tym świecie” [Ortega y Gasset 1949: 81]. Obawy filozofa potwierdzały dwa systemy totalitarne, które pojawiły się wówczas w Europie. Dzisiaj wydaje się jednak, że powody do niepokoju wspaniale podważył rozpad obu tych systemów, w tym w końcu rozpad bolszewickiego bloku wschodniego, który zwolnił miejsce pod budowę demokratycznych państw prawa.

W kulminacyjnym punkcie światowej rewolucji demokratycznej, który miał miejsce w 1989 r., wielu uważało, że demokratyczne państwo prawa w liberalnym, zachodnim wydaniu ostatecznie i bezpowrotnie zwyciężyło przynajmniej w Europie, jeśli nie na całym świecie. W USA Francis Fukuyama ogłosił nadejście „końca historii”, ponieważ cały glob zgodnie przyjmował demokrację w stylu amerykańskim i wszędzie wychodziła na jaw niższość innych systemów rządzenia, w tym ostatnio komunizmu. Politolog przyznawał, że realizację demokracji nadal trzeba, co prawda, gdzieniegdzie udoskonalić. Sama idea nie podlegała już jednak, jego zdaniem, dalszym udoskonaleniom, ponieważ stanowiła ostateczną formę rządów, poprzez którą ewolucja ideologiczna człowieka osiągnęła swój punkt kulminacyjny [Fukuyama 1992].

Taki triumfalizm zaprzecza poglądom Platona i jego następców głoszących, że nawet najlepszy ze wszystkich ustrojów nie trwa wiecznie, nie jest odporny na nadużycia czy dekadencję i wciąż na nowo trzeba wypracowywać sobie to, co dobre, aby nie rozpoczął się proces erozji i perwersji ustroju [Demandt 2012: 39n].

Iluzja ostatecznego zwycięstwa demokracji prysła. Oczekiwanie, że ekspansji liberalnej demokracji na całym święcie nie będzie już można zatrzymać, nie miało się spełnić. Powstania w krajach arabskich, przedwcześnie porównywane przez zachodnich obserwatorów z demokratycznymi rewolucjami w Europie Środkowo-Wschodniej, wywołały wojny domowe, w wyniku których nie powstały obywatelskie systemy rządzenia. Poprzez przeprowadzone gdzieniegdzie wybory w demokratyczny sposób oddano władzę w ręce fundamentalistycznych wrogów liberalnej demokracji, pogrążając państwo w jeszcze 
większym nieszczęściu. Arabska wiosna potwierdziła polityczną filozofię Greków, zgodnie z którą tylko wtedy warto dążyć do demokracji, jeśli jest ona zorientowana na dobro ogółu, a formalna demokratyczna zasada rządów sprawowanych przez naród musi łączyć się z materialną, republikańską zasadą sprawowania rządów dla narodu [Isensee 2006] Ta etyczna intencja nie ogranicza się do demokracji. Jest dostępna również dla ustrojów autokratycznych, monarchii i arystokracji.

Ćwierć wieku po swoim triumfie idea liberalnej demokracji poniosła porażki i straty na całym świecie. Państwa konstytucyjne ${ }^{1}$ borykają się z coraz liczniejszymi problemami, które wystawiają na próbę ich wydajność, sprawność i spójność wewnętrzną. Dopóki trwa konflikt, nie da się przewidzieć, czy i jak państwa te przetrwają próbę.

Poniżej rozważam kilka przykładowych problemów. W różny sposób rozkładają się one na poszczególne państwa konstytucyjne. Odwołuję się przede wszystkim do Niemiec, które mają swoje specyficzne problemy, inne dzielą z sąsiednimi państwami, ale też przez niektóre pozostały niedotknięte. Nie wyklucza to jednak jednoczesnych odwołań do innych krajów.

\section{Naród - nacja - społeczeństwo}

Niemcy są wolne od dążeń secesyjnych, z którymi Wielka Brytania zmaga się w związku ze Szkocją, Hiszpania w związku z Katalonią i Krajem Basków, a Belgia w związku z Flandrią i Walonią. W przypadku separatyzmu demos - naród jako podmiot demokracji - jest wystawiony na próbę. Wola państwowej jedności, która sprawia, że jednostki i grupy łączą się i trwają jako naród, kruszy się. Kwestionuje to sam fundament demokracji. Jeśli ktoś uważał, że idea narodowa całkowicie osłabła w wyniku integracji europejskiej i globalizacji, widzi tu zaprzeczenie swoich poglądów.

Pod względem prawnym naród stanowi związek obywateli danego państwa [Isensee 2004]. Obywatelstwo to status prawny, a więc naród stanowi konstrukt państwowego prawa. Jednak koncepcja ta zyskuje życie polityczne tylko wtedy, kiedy wolą wszystkich przekłada się na powołanie państwowej wspólnoty. Tą uprzywilejowaną wspólnotą jest nacja. Państwo nie jest w stanie dyrygować nacją i jej organizować. Rośnie ona oddolnie, z woli poszczególnych obywateli. Wola ta rodzi się na gruncie określonych realnych lub tylko odczuwanych dyrektyw takich jak język, religia, kultura, geografia, historia czy wielkie narracje [Depenheuer 2011]. Nacja dotyczy kraju i ludzi, nie odwołuje się do aparatu państwowego, tylko do ojczyzny. Udana konstytucja może wzmocnić świadomość narodową, ale nie jest w stanie

1 „Państwo konstytucyjne” to częsty synonim „demokratycznego państwa prawa” i „liberalnej demokracji”. 
jej zastąpić, jak uważają ideolodzy patriotyzmu konstytucyjnego, którzy chcą w ten sposób zrzucić z siebie balast niewygodnej niemieckiej historii [Depenheuer 2010]. To od nich wywodzi się pomysł, że Niemcy powinni bezwarunkowo otworzyć swoje granice przed migrantami z całego świata, nawet jeśli wiąże się to z ryzykiem upadku. Celem miałoby być przetrwanie nie niemieckiego narodu, lecz jedynie jego demokratycznej konstytucji. To negacja nacji wynikająca z nienawiści do własnego narodu.

Nacja nie tworzy określonych praw, lecz określony etos czy patriotyzm, który stwarza z kolei więzy solidarności, spajające wszystkich obywateli. Nacja rośnie i więdnie na przestrzeni dziejów. Jeśli chce przetrwać, musi się ciągle odnawiać w „plébiscite de tous les jours” [Renan 1882].

Nacja nie jest kwestią rachunku zysków i strat. „Unia celna nie jest ojczyzną” - powiedział Renan. Również dzisiaj konstrukcja stworzona z myślą o konkretnych celach, jaką jest UE, choć konieczna i korzystna, nie jest ojczyzną. Przemawia tylko do racjonalnej strony człowieka. Nacja to jednak również uczucia, rodzi polityczne namiętności. To właśnie dlatego - choć może to dziwić - w samym centrum UE, na terytorium Belgii, tak burzliwie rozgrywa się narodowe sprzeczności między Flamandami a Walonami. Jednak UE, która nie opiera się na europejskiej nacji, lecz na państwach narodowych, sama pogrążyła się w kryzysie, jeśli chodzi o jej funkcję i akceptację społeczną. Musi też sama przetrwać secesję Wielkiej Brytanii - brexit.

Demokracja zakłada istnienie spójnej nacji, w której wspólne więzy są wystarczająco silne, aby rekompensować porażki w wyborach i głosowaniach, a zwycięzcy, jak i przegrani podporządkowują się zasadom walki o władzę i wpływy. Demokracji nie można narzucić przypadkowo zlepionym grupom ludzi, jak ma to miejsce w niektórych krajach powstałych z byłych kolonii, które zostały stworzone według potrzeb nie lokalnej ludności, lecz wyłącznie byłych kolonistów. USA nie zważają na to, stawiając się w roli światowego misjonarza, który narzuca demokrację w amerykańskim stylu Irakowi. Skutkiem tego jest widmo wojny domowej, wynikające z trwałego powierzenia władzy szyickiej większości, co sunnicka mniejszość odbiera jako rządy obcych. Wrażliwa mniejszość szybciej pogodzi się z równym dla wszystkich uciskiem ze strony dyktatora niż z trwałym podporządkowaniem rządom większości równych sobie. Tam, gdzie ludność nie stanowi jedności narodowej, rozwiązaniem nie jest demokracja, lecz federalizm plemion czy grup, który umożliwia jedność w pluralizmie i amortyzuje dążenia secesyjne.

Spójność narodowa rodzi problemy nie tylko w państwach, w których określone regiony grożą secesją, lecz również tam, gdzie tworzą się równoległe społeczeństwa złożone 
z migrantów reprezentujących obce kultury, którzy izolują się od miejscowej ludności. Mogą się oni powoływać na prawa podstawowe, aby bronić własnej odmienności i nie dopuścić do przymusu integracyjnego. Państwo nie rozwiązuje problemów, oferując migrantom obywatelstwo i nie żądając w zamian uprzedniej integracji oraz rezygnacji z dotychczasowej przynależności państwowej. W ten sposób zaostrza bowiem raczej niż rozwiązuje istniejące już konflikty społeczne. Jeżeli robi się to - tak jak w Niemczech - na coraz większą skalę, dochodzi do zróżnicowania prawnego na niekorzyść rdzennej ludności, a więc osób, które są „tylko” Niemcami, a nie „również” Niemcami, a więc pozostają nieuchronnie związane $\mathrm{z}$ losem tylko jednego państwa, nie mogąc w razie potrzeby uciec pod opiekę innego.

Najtrudniejsze problemy wynikające z migracji tkwią w oporze islamu wobec integracji, któremu obcy jest duch nowoczesności, a tym samym również rozróżnienie między prawem a moralnością, religią a obyczajem, a także świeckość państwa i pozycja religii w otwartym, pluralistycznym społeczeństwie [Souler-Stagemann 1998; Loschelder 1986:149n; Lagenfeld 2001; Hilgruber 1999]. Sprzeciw kieruje się przeciwko zachodniej kulturze i podstawom państwa konstytucyjnego. Islam ucieleśnia myślenie jednościowe, którego nigdy nie było w chrześcijaństwie, nawet we wczesnych stadiach rozwoju, ponieważ chrześcijanie od początku rozróżniali królestwo boże od królestw ziemskich, władzę duchową od świeckiej, prawo od sumienia, to, co cesarskie, od tego, co boskie. To właśnie te rozróżnienia w toku długiego procesu historycznego wykształciły coś, co nazywamy dzisiaj nowoczesnością [Isensee 2015].

Kultura europejska nie ma powodu, aby zachowywać się wobec islamskiej wyniośle i twierdzić, że ma moralną wyższość. Dla bogobojnego, obyczajnego muzułmanina, który trafił do zachodniego kraju, nowe realia mogą wydać się szokujące, wręcz budzić wstręt - bezwstydny obraz zachowań seksualnych pozbawionych moralności i godności, w tym w szczególności jawnie praktykowanego homoseksualizmu, hedonizmu, braku powagi, dekadencji, świata bez Boga, gdzie już nic nie jest święte. Jednak kultura europejska w swojej realnej postaci nie czerpie legitymizacji z moralności, lecz z wolności wszystkich, którzy do niej należą. Realizacja prawa podstawowego do wolności nie gwarantuje moralnej (ani intelektualnej) jakości, ponieważ wolność w równym stopniu można wykorzystać do czynienie dobra, jak i zła, robienia tego, co mądre, jak i tego, co głupie. Wolność oznacza możliwość wyznaczania sobie własnych praw i brak konieczności podporządkowania się cudzym zasadom, w tym nakazom moralnym i religijnym.

Z prawem do wolności związany jest jednak podstawowy obowiązek, aby tolerować przejawy cudzej wolności i nie reagować wobec nich przemocą. Z tym jednak niektórzy migranci z surowego świata islamu mają trudności. 


\section{3. „Walka z prawicą” a nowa prawica}

Zachodnioniemiecka demokracja miała od samego początku charakter antytotalitarny, starając się utrzymywać równy dystans zarówno wobec narodowego socjalizmu Hitlera, jak i komunizmu Stalina. Postrzegała się jako środek między wrogimi totalitaryzmami - prawicowym i lewicowym [Bracher 1976: 33n; Sontheimer 1976: 18n; Bergsdorf 1983: 103n i 282n]. Dzisiaj ponad podziałami partyjnymi panuje zgodność już tylko w kwestii odrzucenia prawicy. Obywatelskie centrum spotyka się na jednym froncie antyfaszystowskim z pogardzanym wcześniej lewicowym ekstremizmem. System polityczny nie jest już w stanie walczyć na dwóch frontach. Poddaje się na froncie lewicowym, aby tym silniej walczyć na tym prawicowym. To, że od upadku bloku wschodniego demokracji nie grozi niebezpieczeństwo ze strony lewicy, nie podlega dyskusji, przynajmniej dla tych, którzy już wcześniej nie widzieli tutaj niebezpieczeństwa. Tym większa jest jednak wrażliwość na ryzyka związane ze skrajną prawicą. Rzeczywiście w ostatnich latach nasilają się spektakularne zbrodnie. Sprawcy i ich sympatycy spotykają się z jednomyślnym potępieniem i wykluczeniem społecznym. Kiedy tylko pojawia się płomień, natychmiast się go zadeptuje. W tym obszarze demokracja okazuje się bardziej zdolna do obrony niż kiedykolwiek wcześniej. Ta zdolność do obrony jest jednak asymetryczna.

W ramach „walki z prawicą” powstał kartel ugruntowanych partii i mediów, który uprawia rodzaj cenzury w obszarach tematycznych takich jak ochrona klimatu, wspieranie kobiet, migracja, islam, integracja europejska czy kwestie narodowe. Wszystko, co nie pasuje do lewicowo-liberalnego schematu, jest politycznie potępiane, odrzucane jako populizm i przepędzane z kręgu „demokratów” i „ludzi przyzwoitych” maczugą w postaci zarzutu rasizmu, faszyzmu, nacjonalizmu, seksizmu itd. Powstał tutaj pozbawiony dyskursu ugór, który zarasta wszelkiej maści chwastami. Teraz jednak na prawej stronie sceny politycznej pojawia się partia, która podejmuje pogardzane wcześniej tematy i po szybkich sukcesach wyborczych wchodzi do parlamentów (ośmieszając przy okazji badania opinii publicznej), gdzie trafia na zamknięty front obronny ugruntowanych partii sięgający od centrum po lewicę. Nowicjusz jest wrogo nastawiony wobec establishmentu, a ten z kolei ogłasza go wrogiem. Analogicznych wrogów można znaleźć we Francji, Holandii, Austrii i w innych krajach.

Prawicowi pariasi nagle znajdują potwierdzenie swoich poglądów w wyborze Trumpa na prezydenta USA. Tłumione przekonania polityczne nieoczekiwanie znów dają o sobie znać. Jedni widzą w tym zagrożenie dla demokracji, inni z kolei dowód na jej witalność, ponieważ umożliwia przełamywanie skostniałych struktur władzy, usuwanie zarozumiałych liderów opinii, deptanie poprawności politycznej, wyładowywanie politycznego gniewu 
i ucieczkę przed rezygnacją poprzez powrót do urn. Frekwencja wyborcza rzeczywiście rośnie. Zmęczona konsensusem demokracja znów się ożywia. Do polityki wkracza nowa, szokująca nieobliczalność.

\section{Powrót cezaryzmu}

Na obrzeżach Europy - w Rosji czy w Turcji - ale nie tylko tam, demokracja nabiera coraz bardziej autorytarnego charakteru. Pozbywa się więzów praworządności i zapycha źródła własnej legitymizacji, uciskając parlamentarną i pozaparlamentarną opozycję oraz krytyczne media. Instytucje i procedury konstytucyjne zastępuje się plebiscytowymi aklamacjami. Budynek demokratycznego państwa prawa jest drylowany i urządzany pod rządy wybranych przez naród autokratów. Demokratyczna pozostaje jedynie fasada. Cezaryzm, który uważano za martwy, powraca.

Neocezaryzm nie zadowala się władzą wewnętrzną. Ma ambicje imperialne. Rosja stara się znów podporządkować swoim wpływom państwa powstałe $\mathrm{z}$ byłych republik ZSRR, a w miarę możliwości również byłe państwa satelickie w Europie Środkowo-Wschodniej, aby stworzyć w ten sposób wielki obszar, który będzie izolować od zewnętrznych wpływów [por. Schmitt 1939]. Poprzez niezgodną z prawem międzynarodowym aneksję Krymu i rozpętanie wojny secesyjnej na wschodzie Ukrainy, Moskwa zerwała pokój, jakim Europa cieszyła się przez 25 lat po upadku Związku Radzieckiego. Te 25 lat, które właśnie się skończyły, przejdą do historii jako złota epoka starego kontynentu. Teraz nad Europą znów zawisło widmo wojny i ucisku.

Turcja dąży do przynajmniej regionalnej hegemonii. Geograficzna pozycja półwyspu daje jej władzę - może zatrzymać lub biernie przepuścić azjatycko-afrykańską wędrówkę ludów na drodze do Europy, a tym samym szantażować stary kontynent, który stał się bezbronny wskutek hojnych ofert gwarancji poszanowania praw człowieka i związania koniecznością realizacji prawa do azylu.

\section{Europa - złapana w sieć własnych ofert gwarancji poszanowania praw podstawowych} Prawo do azylu odzwierciedla ogólny rozwój praw podstawowych, które w wyniku krajowego i międzynarodowego orzecznictwa przybierają coraz trwalszą formę i bogatszą treść. Tym samym kurczy się swoboda działalności politycznej w poszczególnych państwach. W Niemczech prawo do azylu wprowadzono do ustawy zasadniczej w 1949 r. z myślą o jednostkach proszących o ochronę, nie mogąc nawet przypuszczać, że kiedyś przed drzwiami staną miliony. Od tamtej pory warunki, procedury i konsekwencje były coraz bardziej uszczegóławiane w krajowych i europejskich ustawach oraz orzeczeniach, ale 
zawsze z myślą o pojedynczych osobach ubiegających się o status uchodźcy, nie zaś napierającej masie, jaką obserwujemy w przypadku aktualnej wędrówki ludów.

Osoba, która znajdzie się na terytorium danego państwa (lub UE), może złożyć tam wniosek o przyznanie statusu uchodźcy i otrzymać tymczasowe prawo pobytu aż do momentu, kiedy w postępowaniu administracyjnym lub ew. sądowym postępowaniu odwoławczym zapadnie ostateczna decyzja o tym, czy wnioskodawcy przysługuje azyl [BVerfGE 35, 382 (401 i nast.); Heusch, Haderlein, Schönenbroicher 2016: 65]. Może to trwać wiele lat. Przez ten okres wnioskodawca ma prawo domagać się od państwa, w którym przebywa, utrzymania, jeśli sam nie jest w stanie pokryć jego kosztów [BVerfGE 132, 134 (159 i nast.)]. Oddalenie wniosku o status uchodźcy niekoniecznie musi oznaczać przymus wyjazdu, ponieważ deportacja obwarowana jest prawnymi warunkami. W państwie pochodzenia wnioskodawcy nie mogą grozić nieprzyjemności, które naruszałyby prawa człowieka. Przede wszystkim jednak kraj pochodzenia musi w ogóle wyrazić gotowość, żeby taką osobę z powrotem przyjąć [Kempen 2016: 216n]. Często tak się nie dzieje. Ponadto wciąż można zyskać na czasie, zaskarżając decyzję o deportacji. Zanim nastąpi jej wykonanie, jest jeszcze możliwość ukrycia się w mrowiu nielegalnych, ale życzliwie tolerowanych przez państwo i społeczeństwo migrantów. Może nawet udać się otrzymać (pseudolegalny) azyl w jakimś kościele [Isensee 1995: 665].

Jeżeli ktoś stanął już na terytorium jakiegoś kraju, to jeśli tylko zechce, może zostać praktycznie na zawsze. Ten magiczny efekt występuje nawet wtedy, kiedy uchodźcy docierają tylko do wód przybrzeżnych lub też na pełnym morzu ratuje ich z niebezpieczeństwa statek wojenny pod określoną banderą, choćby to oni sami to niebezpieczeństwo wywołali, zatapiając swoją łódź w pobliżu okrętu. Tak zdecydował Europejski Trybunał Praw Człowieka [ETPC 2012]. Dlatego UE i jej państwa członkowskie nie mogą się obronić przed niechcianymi migrantami poprzez ochronę swoich granic zewnętrznych. Trzeba zapobiec jakiemukolwiek kontaktowi z naszym terytorium. Stąd też podejmuje się próby eksternalizacji ochrony granicy, polegające na powierzaniu zadania zatrzymywania i cofania uchodźców innym państwom takim jak Turcja czy Tunezja. Te one mają uchronić Europę przed koniecznością wywiązania się z obietnic składanych w zakresie gwarancji praw człowieka, które nas przerosły.

\section{Siła ostatniego słowa - sąd konstytucyjny}

Zarówno zasada państwa prawa, jak i demokracja wymagają podziału władzy na władzę ustawodawczą, wykonawczą i sądowniczą. Konstytucja danego państwa realizuje tę zasadę we własny sposób. Jednak przepisy konstytucyjne mogą kształtować praktykę 
tylko w ograniczonym zakresie. Rzeczywistego znaczenia danej władzy nie da się z góry jednoznacznie określić, więc równowagę między trzema władzami trzeba wciąż na nowo starować.

Tam, gdzie obowiązują ustawy, dla kwestii władzy istotne jest to, która z władz ma ostatnie słowo w sprawie wykładni ustawy najwyższej - konstytucji. W teorii konstytucjonalizmu stawia się pytanie o to, kto ma być strażnikiem konstytucji [Schmitt 1931 vs. Kelsen 2008: 58].

W Monteskiuszowskiej koncepcji trójpodziału władzy funkcja strażnika konstytucji nie występuje. Również dzisiaj nie do końca pasuje ona do tego schematu, ponieważ może zachwiać równowagę między władzami, uzyskując nadmierne znaczenie. Mimo to ustrój oparty na trójpodziale władzy tylko wtedy może być w stanie podejmować decyzje i działać, kiedy jeden z organów ma ostatnie słowo w kwestii wykładni konstytucji, wiążące wszystkie inne organy. Kompetencję tę może przejąć każda z trzech władz, a dokładniej każdy z ich najwyższych organów - głowa państwa, co odpowiada monarchii konstytucyjnej i historycznym postaciom demokracji prezydenckiej, zwłaszcza we Francji; parlament, który mówi, co stanowi (niepisaną) konstytucję - jak do dzisiaj ma to miejsce w przypadku niższej izby brytyjskiego parlamentu; władza sądownicza, czy to w formie sądu powszechnego jak w USA, czy też odrębnego sądu konstytucyjnego jak w Austrii czy Niemczech. Trójpodział władzy przyjmuje zróżnicowane formy w odniesieniu do poszczególnych organów i procedur. Komponent demokratyczny dominuje tam, gdzie prawo decydowania o ostatecznej wykładni ma parlament, prezydent lub rząd, a więc ktoś z grona polityków. Komponent praworządności uzyskuje zaś hegemonię w krajach, gdzie ostateczną decyzję podejmuje sąd, zwłaszcza w wypadku odrębnego sądu konstytucyjnego, który ma decydować wyłącznie opierając się na kryteriach prawnych, będąc niezależnym od parlamentu i rządu, ale też posiadając słabszą legitymizację demokratyczną. Według ideału Monteskiusza władza sądu powinna być właściwie „en quelque façon nulle” [Montesquieu 1748: XI, VI].

Typ państwa konstytucyjnego, w którym demokracja łączy się z zasadą praworządności, nie przesądza więc z góry o powołaniu sądu konstytucyjnego. Jeśli mielibyśmy porównać państwo konstytucyjne do domu, musimy pamiętać, że znajduje się w nim wiele różnie urządzonych pokojów. Ta instytucjonalna otwartość nie ginie w prawie UE, które szanuje poszczególne tożsamości narodowe w kształcie, w jakim są one wyrażone w politycznych i konstytucyjnoprawnych strukturach danego członka (art. 4 ust. 2 zd. 2 TUE). Demokracja i praworządność należą do wartości, które stanowią o homogeniczności konstytucyjnej państw członkowskich (vide art. 2 TUE). W zależności od systemu konstytucyjnego określonego państwa członkowskiego zasadom tym można jednak na szczeblu krajowym 
nadawać różne znaczenie i kształt [Komisja Europejska 2016] ${ }^{2}$ Sądownictwo konstytucyjne nie jest obowiązkowe. Jeżeli Wielka Brytania i Dania oraz cztery inne państwa członkowskie nie znają takiej instytucji, nie oznacza to przecież, że mają one braki w realizacji zasad praworządności i demokracji. Jeżeli jednak w jakimś państwie członkowskim istnieje prawo konstytucyjne, UE nie może rozszerzać tam zasięgu i intensywności standardu homogeniczności i kompetencji kontrolnych bardziej niż w wypadku państw członkowskich, które nie mają sądownictwa konstytucyjnego. W przeciwnym razie obowiązywałyby podwójne standardy [Komisja Europejska 2016, przypis 25; Komisja Wenecja 2015]³.

Niemiecki Federalny Sąd Konstytucyjny ma szerokie kompetencje. Jego sędziów wybierają organy polityczne - Bundestag i Bundesrat. Uzyskawszy wybór, sędziowie nie są zdani na sympatię wyborców i nie muszą się obawiać ich niełaski. Decyzje Federalnego Sądu Konstytucyjnego mają pierwszeństwo przed zwykłą ustawą oraz aktami politycznymi. Jedynym kryterium, które bierze pod uwagę Federalny Sąd Konstytucyjny, jest konstytucja. Zabrania mu się własnych rozważań politycznych. Federalny Sąd Konstytucyjny zapewnia zresztą, że nie chce uprawiać polityki. Często jednak nie jest jasne, gdzie kończy się wykładnia konstytucji, a zaczyna polityka. Ostatnie słowo w kwestii tego, gdzie ta granica przebiega, należy do Federalnego Sądu Konstytucyjnego [Roellecke 2005]. Instytucja, która wiążąco decyduje o granicach swojej władzy, tak naprawdę nie ma granic. Sędzia Federalnego Sądu Konstytucyjnego nie musi się obawiać zarzutu naginania prawa, podczas gdy każdy inny sędzia powinien mieć się pod tym względem na baczności. Kto interpretuje konstytucję, ma bowiem władzę rozporządzania jej treścią, rozszerzania jej lub zawężania, wychodzenia ponad jej literalne brzmienie i przeprowadzania zmian w zaplanowany sposób. Federalny Sąd Konstytucyjny wypełnia swoje zadania $z$ intuicją i werwą, hojnie interpretuje granice swojej działalności i w efekcie osiąga sytuację, w której cały porządek prawny jest przeszyty jego orzecznictwem, a więc „skonstytucjonalizowany”. Z prób sił w parlamencie i rządzie wychodził zwycięsko. Cieszy się dużą akceptacją społeczną, chociaż czasem musi też przetrwać kryzys zaufania. Nie zawsze jest odporny na hybrydowe nastroje. Kto już raz zasiadł za sterami władzy, chce ją też wykorzystać [Isensee 1996; Jestaedt, Lepsius, Möllers, Schönberger 2011].

I tak Federalny Trybunał Konstytucyjny wchodzi w rolę ustawodawcy, przyznając osobom ubiegającym się o status uchodźcy świadczenia z pomocy społecznej w tej samej wysokości,

2 Debata orientacyjna kolegium komisarzy na temat ostatnich wydarzeń w Polsce i ram prawnych w dziedzinie praworządności.

3 Komisja Europejska (przypis 25) wymienia jako element praworządności „system kontroli sędziowskiej, w tym sądownictwo konstytucyjne (o ile istnieje)". Podobnie Komisja Wenecka. 
co miejscowej ludności. Sam wyznacza poszczególne stawki, w tym nawet wysokość kieszonkowego, powołując się przy tym wszystkim na nadzwyczaj niedookreśloną konstytucyjną zasadę poszanowania godności ludzkiej [BVerfGE 132, s. 134 (159 i nast.); Por. Isensee 231n]. Mimo że ustawa zasadnicza oddaje małżeństwo pod „szczególną” ochronę wspólnoty państwowej, a więc rozróżnia „szczególną” ochronę od zwykłej, którą cieszą się inne związki, Federalny Sąd Konstytucyjny praktycznie zrównuje z małżeństwem związki jednopłciowe, powołując się przy tym na (niedającą się tutaj samą w sobie zastosować) zasadę równości - drogą małych, szczegółowych uchwał, które nie wywołują dużego poruszenia, ale przyczyniają się do tego, że opinia publiczna przyzwyczaja się do „małżeństw homoseksualnych”, którym Federalny Sąd Konstytucyjny - przynajmniej na razie - odmawia jeszcze atrybutu „małżeństwo” w rozumieniu konstytucyjnoprawnym [BVerfGE 124, 199 (218 i nast.); 126, 400 (416 i nast.); 131, 239 (255 i nast.); 132, 179 (188 i nast.); 133, 59 (86 i nast.); 133, 377 (407 i nast., 413 i nast.)]. Parlament chętnie pozwala się wyręczać w podejmowaniu trudnych decyzji, ponieważ ta materia jest politycznie kontrowersyjna i mogłaby dezorientować grupy wyborców.

Federalny Sąd Konstytucyjny przejmuje też niekiedy prawdziwie parlamentarne zadanie bycia forum narodu, kiedy niemiecki Bundestag podczas debaty o brzemiennych w skutkach kwestiach takich jak europejska unia walutowa wykazuje się jednogłośnością i nie pozwala dojść do słowa nielicznym oponentom, chociaż mogliby oni przemówić w imieniu dużej liczby poirytowanych obywateli, jeśli nie ich większości. Prawno-polityczne argumenty oponujących posłów zostają wysłuchane dopiero przed Federalnym Sądem Konstytucyjnym, a przy okazji rozprawy docierają również do opinii publicznej.

Możliwości Federalnego Sądu Konstytucyjnego nie sięgają jednak nieba. O to dba UE, która absorbuje kompetencje państw członkowskich, a tym samym relatywizuje ich suwerenność. Oczywiście Federalny Sąd Konstytucyjny odczuwa to w mniejszym stopniu niż organy władzy ustawodawczej i wykonawczej. Federalny Sąd Konstytucyjny próbuje zachować nadrzędność konstytucji również w procesie integracji [Kirchhof 2012: 43 ;Isensee 2013: 352]. Co do zasady obstaje przy wytycznych niemieckiej ustawy zasadniczej. W praktyce ustępuje jednak w poszczególnych przypadkach. Na razie nie da się jeszcze przewidzieć ostatecznego rozwiązania tego problemu.

\section{Ponadnarodowy wymiar demokratycznego państwa prawa}

28 państw przeniosło swoje istotne kompetencje na szczebel UE, a wraz z nimi również gwarancje ich praworządnego wykonywania. Demokratyczna legitymizacja przechodzi od narodów państw członkowskich na UE w okrojonej formie - bezpośrednio poprzez 
wybór posłów do Parlamentu Europejskiego i pośrednio (choć trochę silniej) poprzez rządy państw członkowskich [Kirchof 2012: 55n]. Kształt demokratycznego państwa prawa w Europie uległ przez to trwałym zmianom. Funkcjonuje ono dzisiaj na dwóch szczeblach - narodowym i ponadnarodowym.

UE i jej państwa członkowskie wyznają wspólne wartości. UE widzi się w roli obrońcy, a może nawet cenzora demokracji i praworządności w państwach członkowskich. Próba nałożenia na Austrię sankcji za naruszenie wspólnych wartości w związku z utworzeniem niepożądanego rządu koalicyjnego okazała się niezgodną z traktatami ingerencją w suwerenność państwa członkowskiego, motywowaną polityką partyjną. Działanie to zakończyło się politycznym blamażem Unii. Trudno na razie jednoznacznie ocenić, czy wyciągnęła z tego wnioski, słuchając często aroganckich i nietaktownych uwag formułowanych przez europejskich polityków na temat Węgier i Polski. Prawo pierwotne UE opiera się w każdym razie na zasadzie, że państwa członkowskie same muszą przetrwać i rozwiązać swoje konflikty konstytucyjne.

Historycznym źródłem organizacji ponadnarodowej jest wspólny rynek wewnętrzny, który rozwijał się powoli i trwale, przejmując wraz z państwową substancją swoich państw członkowskich również ich wspólne struktury konstytucyjnoprawne. Wspólny rynek wewnętrzny pozostał twardym jądrem Unii. Nie imają się go kryzysy, które od lat wstrząsają przybudówkami, o które Unia poszerzała się od traktatu z Maastricht. Kryzysy te są skutkiem gorączkowej ekspansji w ostatnich latach - prawodawstwa niebiorącego pod uwagę możliwości i poziomu narodowych administracji, które odpowiadają za jego wykonywanie; wprowadzenia wspólnej waluty bez niezbędnego fundamentu w postaci wspólnych struktur budżetowych; likwidacji wewnętrznych granic bez zapewnienia skutecznej ochrony granic zewnętrznych; systemu redystrybucji uchodźców bez gotowości do solidarności po stronie mających uczestniczyć w nim państw. W ramach działań podejmowanych w celu walki z kryzysami, za które Unia sama ponosi winę, nagina się $\mathrm{w}$ trybie awaryjnym lub całkowicie zawiesza ścisłe normy traktatowe (jak np. gwarancje stabilności unii walutowej). Kwestionuje się podział kompetencji między oboma szczeblami. Struktury praworządności tracą siłę i formę.

Demokratyczne państwo prawa musi sprostać zmieniającym się wyzwaniom w warunkach niepewności. To jednak zupełnie normalne w historii ludzkiej egzystencji. Trudno zorientować się nawet w teraźniejszości. Prognozy są zawsze niepewne. Mylić mogą się nawet historycy - „prorocy z twarzami zwróconymi do tyłu”. Obszary tematyczne i ogniska kryzysu, 
które musnęliśmy, to tylko mały wybór. Nieprzewidywalne są jednak także strumienie energii i jak na razie sprawnie działające funkcje.

Państwowość oparta na wolności swoich obywateli jest szczególnie krucha, ale - jeśli zachodzi taka potrzeba - może się „oddolnie” przywrócić i odnowić. Demokratyczne państwo prawa w Europie może się, co prawda, w niektórych miejscach psuć, jednak mimo to w ostatecznym rozrachunku okazuje się ono stabilne i wydajne. Reformatorzy mają pole do popisu, dla proroków upadku nie wystarcza materiału.

\section{Po drugiej stronie horyzontu państwa konstytucyjnego - terroryzm}

Dotychczasowe rozważania mieszczą się w ramach państwowego porządku prawnego i jego utrwalonych kategorii. Ramy te rozsadza jednak terroryzm. Ofiary zamachów są środkiem do celu, jakim jest zniszczenie poczucia bezpieczeństwa wśród ludności i podporządkowanie rządu swoim postulatom. Terroryzm działa na całym świecie, jest potencjalnie wszechobecny. Jego mobilność pozwala uderzyć wszędzie i w dowolnym momencie zrekrutować bojowników ukrywających się zarówno w górskich wioskach Pakistanu, jak i na niemieckich uniwersytetach.

To nieznające granic niebezpieczeństwo wymyka się ograniczonym terytorialnie przepisom regulującym działanie policji w poszczególnych państwach. Policjanci nie są w stanie zatrzymywać terrorystów poprzez współpracę z zagranicznymi kolegami, ponieważ nie dysponują bronią, która pozwalałaby skutecznie odpowiedzieć na atak. To jedna z przyczyn tego, że niektóre państwa uciekają się do środków militarnych i wypowiadają terroryzmowi wojnę. Nie jest to jednak wojna w rozumieniu prawnomiędzynarodowym. Międzynarodowe prawo wojenne dotyczy bowiem wojny między państwami. Teraz jednak państwa walczą z przeciwnikiem, który nie jest państwem - z osobami „prywatnymi”, które, lepiej czy gorzej powiązane, działają w sposób planowy lub spontaniczny. Wojna ta nie zna prawnych zasad, które wiązałyby obie strony. Nie istnieje żadne wspólne ius in bello. Terrorysta nie podporządkowuje się ani prawu, ani moralności. Państwo nie zmierza - jak w przypadku tradycyjnej wojny międzypaństwowej - do tego, by pokonać wroga, a na końcu zawrzeć z nim pokój. Celem jest wytępienie terroryzmu.

Terroryzm wysadza nie tylko pojazdy, budynki i ludzi, ale też pojęcia. Chwieją się tradycyjne rozróżnienia występujące w prawie krajowym i w prawie międzynarodowym - rozróżnienia między:

- zwalczaniem zagrożenia, jego prewencją a ściganiem,

- bezpieczeństwem wewnętrznym a zewnętrznym, 
- policją a wojskiem,

- cywilami a żołnierzami,

- przestępczością a wojną,

- osobą naruszającą prawo policyjne a wrogiem politycznym.

Największą irytację wzbudza zamach samobójczy. Terrorysta, który w imię wielkiej sprawy sam wysadza się w powietrze, prowadząc za sobą na śmierć innych, kpi z przesłanek państwa konstytucyjnego - założenia, że każdemu człowiekowi drogie jest własne życie, że kulminacją naturalnej, uzasadnionej korzyści własnej jest wola życia, a wola ta kieruje rozsądkiem politycznym. Państwo jako racjonalny konstrukt utworzony z myślą o realizacji celów pochodzących z wewnętrznego świata jednostki nie zna wyższego celu niż ochrona zdrowia i życia. To klasyczna filozofia usprawiedliwiająca Thomasa Hobbesa, głosząca, że troska o zachowanie życia i zdrowia jest tym, co sprawia, że ludzie łączą się w państwo, że celem istnienia państwa jest ochrona życia i zdrowia oraz że państwo może się domagać posłuchu obywateli tylko w granicach swojej zdolności i gotowości do skutecznego zapewnienia tej ochrony. Najostrzejszym ze wszystkich środków państwowego przymusu byłoby pozbawienie życia. Liberalny ustrój czyni jednak wszystko, żeby zapobiec wykorzystaniu właśnie tego środka. Potępia wojnę zaczepną i zakazuje stosowania kary śmierci. Policyjny strzał ratunkowy pozostaje jedynie krytyczną ultima ratio. Obowiązki ochronne wynikające z praw podstawowych zmierzają do tego, by w miarę możliwości zapobiec zagrożeniu i ryzyku dla życia i zdrowia, również takiemu, które wiąże się ze środowiskiem, techniką czy żywnością. Te regulacje i sankcje państwa prawa są tak stopniowane, aby trzymać się jak najdalej od ingerencji w ciało i życie, które ucieleśniają godność ludzką.

Liberalny system prewencji i sankcji upada w zetknięciu z islamskim zamachowcem, który nie boi się śmierci i nie zna żadnej ziemskiej korzyści własnej poza, co najwyżej, pragnieniem ziemskiej pośmiertnej sławy. „Qui potest mori, non potest cogi”. Terrorysta, który osiągnął ten poziom wewnętrznej wolności, nie da się złapać w chytry plan Kanta, żeby państwo prawa oprzeć nie na moralności człowieka, lecz na jego korzyści własnej. Zdaniem filozofa mechanizm natury prowadzi konflikt egoistycznych skłonności człowieka do powszechnego rozsądnego przekonania o tym, że należy się podporządkować przymusowi ustawy, aby w ten sposób pielęgnować i zabezpieczać pokój, zarówno wewnętrzny, jak i zewnętrzny. Myśliciel uważa, że problem ten dałoby się rozwiązać nawet w narodzie diabłów. Oczywiście czyni przy tym pewne zastrzeżenie: „jeśli tylko mają rozum” [Kant 1964: 191]. Rozumem jest tu jednak zdolność do celowego działania z myślą o samoza-

4 Parafraza sentencji Seneki: „Cogi qui potest, nescit mori” (Hercules furens, 426). 
chowaniu. Właśnie tego rodzaju rozumu nie ma terrorysta, któremu nie zależy na życiu, a jedynie na wielkiej sprawie, która warta jest każdej ofiary. Terroryzm jest egzageracją w czystej formie, państwo prawa natomiast państwem miary [Eichenberger 1980: 165].

Państwo prawa nie pozwala jednak terroryzmowi narzucać sobie kryteriów postępowania. Prowadzi asymetryczną walkę z przeciwnikiem, który nie ma żadnych zahamowań prawnych czy etycznych. Jeżeli terrorysta wypowiada wojnę państwu prawa, państwo prawa nie robi mu tej przyjemności i nie przyjmuje tego oświadczenia, zniżając się do jego poziomu urągającemu prawu i moralności. Nie traktuje terrorysty jak wroga, lecz jako przestępcę, stawiając mu czoła w ramach prawa i dopuszczalnych w nim środków. Szanuje w ten sposób godność ludzką, której nie traci nawet ten, kto w okropny sposób narusza godność innego człowieka. Demokratyczne państwo prawa w Europie sprostało dotychczas wyzwaniu, jakie postawił przed nim terroryzm. Daje to nadzieję, że tak będzie też w przyszłości.

tł. z jęz. niemieckiego Maciej Zgondek

Redakcja dziękuje Fundacji Konrada Adenauera w Polsce za sfinansowanie tłumaczenia tekstu.

Josef Isensee - filozof prawa, profesor nauk prawnych, wieloletni wykładowca Uniwersytetu w Bonn, jego zainteresowania badawcze obejmują kwestie praw podstawowych, naukę o państwie, teorię prawa konstytucyjnego; doktor honoris causa Uniwersytetu Kardynała Stefana Wyszyńskiego w Warszawie, współredaktor (wraz z P. Kirchofem) 13-tomowego podręcznika Handbuch des Staatsrechts der Bundesrepublik Deutschland. Opublikował m.in.: Subsidiaritätsprinzip und Verfassungsrecht (1968, 2. wydanie 2001), Recht als Grenze - Grenze des Rechts (2009). 


\section{Bibliografia:}

Asylverfahrensgesetz $\$ 55$.

AufenthG $\$ 60$.

Bergsdorf W. (1983), Herrschaft und Sprache, Pfullingen.

Bracher K. D. (1976), Zeitgeschichtliche Kontroversen um Faschismus, Totalitarismus und Demokratie.

BVerfGE 124, 199 (218 i nast.); 126, 400 (416 i nast.); 131, 239 (255 i nast.); 132, 179 (188 i nast.); 133, 59 (86 i nast.); 133, 377 (407 i nast., 413 i nast.).

BVerfGE 132, 134 (159 i nast.).

BVerfGE 132, s. 134 (159 i nast.).

BVerfGE 35, 382 (401 i nast.).

Demandt A. (2012), Wie scheitern Demokratien?, w: „Politisches Denken”, Berlin, s. 39-59.

Depenheuer O. (2010), Funktionen der Verfassung, w: tenże (red.), Verfassungstheorie, 2010, \$16 numer boczny 45 i nast.

Depenheuer O. (2011), Erzählungen vom Staat.

Eichenberger K. (1980), Freiheit als Verfassungsprinzip: Der Staat des Maßes, w: tenże, Der Staat der Gegenwart.

ETPC, wyrok z 23.02.2012, w: NVwZ 2012, s. $809(812,816)$.

Fukuyama F. (1992), The End of History, Nowy Jork.

Heusch A., Haderlein N., Schönenbroicher K. (2016), Das neue Asylrecht, München.

Hillgruber Ch. (1999), Der deutsche Rechtsstaat und der muslimische Kulturimport, w: JZ.

Isensee J. (1995), Die karitative Betätigung der Kirchen und der Verfassungsstaat, w: J. Listl/D. Pirson (red.), Handbuch des Staatskirchenrechts der Bundesrepublik Deutschland, tom 2.

Isensee J. (1996), Bundesverfassungsgericht - quo vadis?, w: „Verhandlungen des 61. Deutschen Juristentages", Karlsruhe, Sitzungsberichte tom II/1, H Festvortrag.

Kelsen H. (2008), Wer soll der Hüter der Verfassung sein?, w: tenże, Wer soll der Hüter der Verfassung sein?, Tübingen.

Isensee J. (2006), Gemeinwohl im Verfassungsstaat, w: tenże/Paul Kirchhof (red.), Handbuch des Staatsrechts der Bundesrepublik Deutschland (= HStR), tom IV, 2006, $\$ 71$ numer boczny 22 i nast.

Isensee J. (2013), Der Selbstand der Verfassung, w: AöR 138.

Isensee J. (2015), Christliches Erbe im organisierten Europa, w: JZ.

Isensee J., Staat und Verfassung, w: HStR II, 2004, $\$ 15$ numer boczny 119 i nast.

Jestaedt M., Lepsius O., Möllers Ch., Schönberger Ch. (2011), Das entgrenzte Gericht, Eine kritische Bilanz nach sechzig Jahren bundesverfassungsgericht, Berlin.

Kant I. (1964), Zum ewigen Frieden, w: tenże, Werke (red. Von Wilhelm Weischedel); tom VII.

Kempen B. (2016), Abschiebung, w: O. Depenheuer/Ch. Grabenwarter (red.), Der Staat in der Flüchtlingskrise. Kirchhof P. (2012), Der deutsche Staat im Prozeß der europäischen Integration, w: HStR X.

Komisja Europejska, Zestawienie informacji z 13.01.2016 r.

Komisja Wenecka, Opinion on Amendments to the Act of 25 June 2015 on the Constitutional Tribunal of Poland $z$ 11.03.2016 $r$. (Opinion no. 833/2015).

Langenfeld Ch., 2001, Integration und kulturelle Identität zugewanderter Minderheiten.

Loschelder W. (1986), Der Islam und die religionsrechtliche Ordnung des Grundgesetzes, w: „Essener Gespräche" 20 (1986).

Montesquieu (1748), De l'esprit des lois.

Ortega y Gasset (1949), Der Aufstand der Massen.

Renan E. (1882), Qu'est ce qu'une nation?.

Roellecke G., Aufgaben und Stellung des Bundesverfassungsgerichts im Verfassungsgefüge, w: HStR III, $205, \$ 67$.

Schmitt C. (1931), Der Hüter der Verfassung, Weimar.

Schmitt C. (1939), Völkerrechtliche Großraumordnung mit Interventionsverbot für raumfremde Mächte. Sontheimer K. (1976), Das Elend unserer Intellektuellen, Hamburg.

Spuler-Stegemann U. (1998), Muslime in Deutschland. 